\title{
THE INFLUENCE OF SUMMER UPWELLING AT THE WESTERN BOUNDARY OF THE CANTABRIAN COAST
}

\author{
Prego, R..$^{{ }^{*}}$, Varela, M. ${ }^{2}$, deCastro, M. ${ }^{3}$, Ospina-Álvarez, N. ${ }^{1}$, García-Soto, C ${ }^{4}$, Gómez-Gesteira, M. ${ }^{3}$ \\ ${ }^{1}$ Marine Research Institute (CSIC). 36208 Vigo, Spain. \\ ${ }^{2}$ Oceanographic Center of A Coruña (IEO). 15001 A Coruña, Spain. \\ ${ }^{3}$ Environmental Physics Laboratory (EPhysLab). Faculty of Sciences (Univ. Vigo), 32004 Ourense, Spain. \\ ${ }^{4}$ Oceanographic Center of Santander (IEO). 39004 Santander, Spain. \\ * Corresponding author: \\ Dr. Ricardo Prego. \\ Marine Research Institute (CSIC). \\ Eduardo Cabello, 6. E-36208 Vigo, Spain. \\ E-mail: prego@iim.csic.es
}

\begin{abstract}
Recent characterizations of atmospheric conditions favourable to upwelling events in the Western Cantabrian Sea have stressed the need to analyze the significance of the orientation of the coast on the phenomenon of upwelling. Surface-wind fields for the northwestern Galician marine area were provided by the QuikSCAT satellite and a SST map was elaborated using the NASA GHRSST satellite data. A cruise was conducted aboard the RV Lura in June 2009 during northern prevailing winds. Data of thermohaline variables, concentration of dissolved oxygen, dissolved inorganic nitrogen, chlorophyll, dissolved and particulate organic carbon and nitrogen and phytoplankton abundances were obtained. When the upwelling developed west of the Cape Ortegal was strong, the Eastern North Atlantic Central Water mixed with coastal water eastward of the Cape and the upwelled seawater reached the westernmost of the Northern Galician Rias, the Ria of Ortigueira. Incoming seawater was poor in nitrate and chlorophyll concentrations when compared to that of the upwelling events in the Western Galician Rias. The phytoplankton assemblages were typical of summer upwelling blooms in the latter Rias but phytoplankton biomass was lower in the Ria of Ortigueira and the species were indicatives of initial (inner ria under continental influence) and advanced (outer ria under upwelling inputs) stages of phytoplankton succession. The observed process arose when the upwelling edge-zone reaches a change of coastal orientation as may also occur in other upwelling regions.
\end{abstract}

Keywords: thermohaline variables; nutrient; phytoplankton; Prior-Ortegal upwelling; coastal orientation; NW Spain.

\section{INTRODUCTION}

The coastal marine area on the north western shelf of the Iberian Peninsula is dominated from May to September by strong coastal upwelling events (Fraga, 1981; Torres and Barton, 2007) of Eastern North Atlantic Central Water (ENACW). South of Cape Finisterre, upwelling reaches the Western Galician Rias (Tenore et al., 1982; Blanton et al., 1984). North of Cape Finisterre the core of the upwelling is situated between the Capes Prior and Ortegal (Prego and Bao, 1997). Although upwelling has not been investigated intensively in this area, the nutrients richness (Prego et al., 1999) is known. To the south of Cape Prior the influence of upwelling is lower due to the local topography, which confines the Artabro Rias water to near the coast (Prego and Varela, 1998; Varela et al., 2001). On the other hand, to the east of Cape Ortegal, favourable upwelling conditions were recently shown by Alvarez et al. (2010). Specifically, ENACW was detected on the shelf outside the Northern Galician Rias during an upwelling episode in July 2008 (Ospina-Alvarez et al., 2010) while winter mixing seawater upwelled in February 2008 (Alvarez et al., 2009). Galicia 
is situated in the north-western corner of the Iberian Peninsula (Figure 1) where the coastal orientation changes east of Cape Ortegal, between Capes Ortegal and Finisterre and south of Cape Finisterre. Gómez-Gesteira et al. (2006) and Alvarez et al. (2008) observed that the Ekman transport patterns vary in intensity and direction along the coast. To that effect, coastal orientation can play a significant role in the upwelling behaviour. Elsewhere, the Algarve coast in Portugal and the northern coast of Morocco are affected only weakly or intermittently by coastal upwelling since in these cases the coastlines are aligned at a significant angle to the dominant winds (Barton, 1998) which is also true of the northern coastline of Galicia, at the western extremity of the Cantabrian coast.

The oceanographic interest in the Galician Rias mainly derives from the knowledge of upwelling acquired during the study of the Western Rias. In contrast, in the Northern Rias the intrusion of ENACW affects the continental shelf but not the rias and reaches its limit of influence near the mouth of the Ria of Ortigueira (Ospina-Alvarez et al., 2010), but upwelling does not reach the surface waters. The cruise was planned to coincide with conditions favourable to intense upwelling using previous information provided by the meteorological agencies. These weather conditions occurred in mid-June 2009. Physical, chemical and biological data were collected at several stations distributed across the Ortigueira shelf. The aim of this research was: (i) to characterize a well developed upwelling event in the Ria of Ortigueira, and (ii) to analyze the significance of the coastal orientation on this phenomenon.

\section{MATERIALS AND METHOD}

\subsection{Study area}

The Ria of Ortigueira (Fig.1) is one of the Northern Galician Rias located to the east of Cape Ortegal characterized by their own distinct tectonic and oceanographic framework which contrasts to those of the Western and Middle Galician Rias. The Ria of Ortigueira is $11 \mathrm{~km}$ long and has a surface area of $38 \mathrm{~km}^{2}$; it is situated between Cape Ortegal and Cape Estaca-de-Bares $\left(43^{\circ} 47.5^{\prime} \mathrm{N}\right)$, which is the northernmost point of the Iberian Peninsula and the western boundary of the Cantabrian Sea, and has a wet temperate oceanic climate. The ria has two parts: (a) the inner part, where the Mera River discharges (mean annual flows of $4.2 \mathrm{~m}^{3} \cdot \mathrm{s}^{-1}$ ), is a shallow mesotidal zone of mudflats that is partially enclosed by a well-developed beach barrier; and (b) the middle-outer part, with a mouth which is $5 \mathrm{~km}$ wide and $30 \mathrm{~m}$ deep which is open to the northern swell, and where mainly ocean processes control its hydrodynamic.

\subsection{Meteorological and Satellite data}

Surface wind fields for June 2009 were provided by the QuikSCAT satellite, and retrieved from the Jet Propulsion Laboratory web site (http://podaac.jpl.nasa.gov/quikscat/ qscat_data.html). The data set consists of global grid values of meridional and zonal components of wind measured twice daily on an approximately $0.25^{\circ} \times 0.25^{\circ}$ grid with global coverage. Statistical comparison between QuikSCAT data and numerical models was carried out along the Galician coast (Penabad et al., 2008) and revealed similar results from models and satellite data.

Following Alvarez et al. (2008) UI can be defined as the component of Ekman transport in the direction perpendicular to the shore-line, then the $Q_{y}$ component of the Ekman transport can be considered as the UI for the Northern Galician Rias $\left(U \mathrm{Ul}=+Q_{\mathrm{y}}\right)$. Positive values of $\mathrm{UI}\left(\mathrm{m}^{3} \cdot \mathrm{s}^{-1} \cdot \mathrm{km}^{-1}\right)$ indicate upwelling-favourable conditions.

Maps of Sea Surface Temperature were elaborated using the GHRSST L4 OSTIA data base that combines measurements of thermal infrared satellite sensors (AVHRR, MODIS, AATSR and SEVIRI) microwave satellite sensors (AMSR-E and TMI) and in situ data from drifting and moored buoys. The data set has a precision of $0.1 \mathrm{~K}$, a spatial resolution of $0.05^{\circ} \times 0.05^{\circ}$ and a daily temporal resolution. The NASA tool POET (PO.DAAC Ocean ESIP Tool) was used to plot directly the original data set with no interpolation. No land mask was used. Details of the data processing can be found at the following NASA website: ftp://podaac.jpl.nasa.gov/GHRSST/doc/GHRSST_guide_doc. pdf. 


\subsection{Seawater column sampling and analyses}

The cruise was conducted aboard the RV Lura on June $23^{\text {rd }}, 2009$ following a period of eight days of northern prevailing winds in order to analyze the oceanographic characteristics in the water column of the Ria of Ortigueira during an intense upwelling event. Thermohaline variables were measured in two sections with a CTD SeaBird-25 with PAR and Fluorescence sensors placed in a General Oceanic Mini-Rosette. Vertical profiles of temperature and salinity were obtained at five stations (60 $\mathrm{m}$ depth) parallel to coast from Cape Prior to Cape Ortegal (Fig.1, lower-right panel) and five stations inside the Ortigueira shelf (Stations A to E; Fig.1). Moreover, in the Ortigueira transect, seawater for chemical and biological sub-sampling was collected at each station $(0,5,10,20,30,40$ and 50 m depth-permitting) using General Oceanic Niskin bottles of 5L.

Dissolved oxygen concentrations were measured the day after sampling day by Winkler titration and saturation percentages were calculated. Seawater samples were frozen onboard at $20^{\circ} \mathrm{C}$ and later analyzed in the laboratory: for nitrate, nitrite and ammonium using a QUAATRO autoanalyzer system (Bran+Luebbe) according to standard colorimetric methods (Hansen and Koroleff, 1999) and dissolved organic carbon (DOC) and nitrogen (DON) were determined using a Shimadzu TOC-VCSH analyzer by high temperature catalytic oxidation (HTCO), following the procedure described by Álvarez-Salgado and Miller (1998). Chlorophyll- $a$ samples were filtered $(\approx 250 \mathrm{~mL})$ on board through a Whatman $\mathrm{GF} / \mathrm{F}$ filter and frozen at $-20{ }^{\circ} \mathrm{C}$; later, their concentrations were determined by spectrofluorimetry (Neveux and Panouse, 1987) after extraction with $90 \%$ acetone. Replicates of chemical variables showed an error range lower than 1\%. Particulate organic carbon (POC), particulate organic nitrogen (PON) and phytoplankton abundances of different groups were measured at three stations (A, C and E; Fig.1). Seawater aliquots were filtered on board through glass microfiber filters (Whatman GF/F); in the case of POC, carbonate was not removed from the filters because its contribution represents only up to $2 \%$ of total particulate carbon (Fernández et al., 1995). POC and PON were determined using a FlashEA 11-12 Termoquesth $\mathrm{CNH}$ analyzer. Samples for quantification of phytoplankton were preserved in Lugol's solution to be examined later under a Nikon Eclipse TE $2000 \mathrm{U}$ inverted microscope. The nomenclature for species was considered following Tomas (1997). For phytoplankton sizes, the criterion proposed by Sieburth et al. (1978) was used.

\section{RESULTS}

\subsection{Upwelling episode in northern Galician coast}

The upwelling index (Fig.2) showed the existence of favourable upwelling conditions in the Ria of Ortigueira during the second half of June 2009. The event began slowly on the $14^{\text {th }}-18^{\text {th }}$ of June with UI values ranging from 100 to $300 \mathrm{~m}^{3} \cdot \mathrm{s}^{-1} \cdot \mathrm{km}^{-1}$ and it had a sharp increase of up to 1400 $\mathrm{m}^{3} \cdot \mathrm{s}^{-1} \cdot \mathrm{km}^{-1}$ during the next few days. The evolution of the upwelling event was followed daily by means of sea surface temperature images offshore of the northern and northwestern coast of Galicia (Fig.2). The isotherms show how the cold surface seawater (below $16^{\circ} \mathrm{C}$ ) moved eastward from after the $17^{\text {th }}$ June, generating a zonal temperature gradient. Then the influence of the upwelling developed between Capes Prior-Ortegal northward to the Cape Ortegal and the ENACW mixed with coastal seawater moved across the Ortigueira shelf (Fig.2). Hence, from $17^{\text {th }}$ June to $23^{\text {rd }}$ June the seawater temperature droped from $17^{\circ} \mathrm{C}$ to $14^{\circ} \mathrm{C}$ at the part of the shelf located in front of the Ria of Ortigueira, in agreement with the detected trend in UI.

Vertical profiles collected between the Capes of Prior and Ortegal (St.1-5; Fig.3) on the $23^{\text {rd }}$ June detected cold surface seawater, with temperatures ranging from 13.1 to $13.5^{\circ} \mathrm{C}$ at $5 \mathrm{~m}$ depth. Seawater temperature also decreased to $12.6-12.7^{\circ} \mathrm{C}$ at $40 \mathrm{~m}$ depth with a salinity of 35.67-35.68 during the maximum of the upwelling episode. This can be seen to be associated, from the TS diagram, with coastal subsurface seawater partially mixed with ENACW in the core of Prior-Ortegal upwelling. In comparison, near the bottom of St.D-E (Fig.3) salinities (35.65-35.66) 
and slightly lower temperatures $\left(12.5^{\circ} \mathrm{C}\right)$ were observed off the Ria of Ortigueira (St.D-E, Fig.3), i.e. on the edge of upwelling.

\subsection{Biogeochemical conditions in the Ria of Ortigueira}

The subsurface seawater on the Ortigueira shelf (St.C-E, Fig.3) is similar, according to the TS diagram, to that observed in the coastal section between the aforementioned capes. The offshore upwelled seawater, both at the shelf and in the middle ria, is traced by the isohaline of 35.65 in Figure 4. Inshore of station B the outflow from the inner ria is clearly shown by the higher temperatures (up to $15.5^{\circ} \mathrm{C}$ ) and a decreased salinity of 35.3 . The salinity drop was small due to the low freshwater flow during June 2009 (Mera River flow: $2.7 \mathrm{~m}^{3} \cdot \mathrm{s}^{-1}$ ).

Inside the Ria (St.B-D) and its nearby shelf nitrate (Fig.4) concentrations increased with depth as much as 5.8 times that measured near the bottom at station E. The opposite occurred in the upper water column of stations $B$ and $C$ where nitrate was practically depleted. Nitrate depletion occurred (surface layer in Fig.4) in the chlorophyll maximum zone (6.1-7.3 $\mu \mathrm{g} \cdot \mathrm{L}^{-1}$ ), C/N atomic ratio of (5.9-6.2) and over-saturation of dissolved oxygen of 109-120\%. Dissolved organic carbon (DOC) also showed high concentrations, $\approx 100 \mu \mathrm{M}$, but lower than those values in the water exported from the inner ria (130-150 $\mu \mathrm{M}$ of DOC); the same trend was exhibited by dissolved organic nitrogen: 10-13 $\mu \mathrm{M}$. A remineralisation area was detected offshore of the ria with a maximum at $20 \mathrm{~m}$ depth at stations D-E. This was reflected by the dissolved oxygen saturations of $85-90 \%$ and nitrite and ammonium concentrations of $0.24-0.57$ and $1.8-2.9 \mu \mathrm{M}$, respectively.

The results of phytoplankton abundances in the study zone are shown in Table 1. Diatoms were, by far, the most abundant group, even more abundant than flagellates. Chaetoceros socialis and $C$. affinis were the dominant taxa. A clear gradient was observed, with higher abundances inside the ria and a monotonic decrease offshore. The opposite occurs with other taxa such as Leptocylindrus danicus, L. minimus or Guinardia delicatula, which showed an increase in abundance offshore.

\section{DISCUSSION}

The general feature of the upwelling event investigated in the Ria of Ortigueira was similar to that observed in the Western Rias: a simple circulation cell where the rise of subsurface seawater occurred landward inside the ria (Gómez-Gesteira et al., 2003 and the references cited therein). Apart from this general similarity to the Western Shelf of Galicia, which is a good example of intense upwelling of ENACW (Fraga, 1981), significant differences of the hydrographical, biogeochemical and phytoplankton aspects were detected in the case of Ortigueira.

On the one hand, the upwelling process in the Ria of Ortigueira was strong according to the Barton (1998) criteria with UI higher than $1000 \mathrm{~m}^{3} \cdot \mathrm{s}^{-1} \cdot \mathrm{km}^{-1}$, which is reflected in the fact that the surface temperature was lower than $14^{\circ} \mathrm{C}$ (Fig.4). However, the nature of upwelled seawater, ENACW mixed with coastal seawater, was different to that which upwells during similar events in the Western Rias. A recent study in the Northern Rias during summer has emphasized that upwelling seawater remained outside these rias only affecting the neighbouring shelf (OspinaAlvarez et al., 2010). In the present wind-induced upwelling chlorophyll- $a$ concentrations were higher in the Ortigueira Ria than in the aforementioned study but a similar inner-outer pattern, or continental-upwelling influence, was observed in this ria.

On the other hand, the mixed ENACW and the scarce shelf remineralisation caused lower concentrations of nutrient salts in the incoming seawater to the Ria of Ortigueira $(7 \mu \mathrm{M}$ of dissolved inorganic nitrogen, Fig.4) as compared to the Western Rias (13 $\mu \mathrm{M}$ of dissolved inorganic nitrogen; Prego, 1994; Alvarez-Salgado et al., 1996). This finding is a good example of the different nutrient availability along the Galician continental shelf as pointed out by Prego et al. (1999): upwelled water north of Cape Finisterre is less rich in nitrate and phosphate. A lower 
nutrient concentration results in lower phytoplankton biomass. The chlorophyll-a concentration on the surface in the Ria of Ortigueira was lower than that measured in other Galician rias under upwelling conditions (Varela et al., 2005).

The phytoplankton assemblages in the Ria of Ortigueira were typical of summer upwelling blooms in the rias around the Cape Finisterre (Varela et al., 2005; 2008) but phytoplankton biomass was lower during the Ortigueira event. The species composition showed the typical seaward asymmetry due to the temporal evolution of the upwelling process, i.e. the initial phases of phytoplankton succession prevailing in the inner ria while the final phases dominating in the ria mouth (Margalef, 1978). In the Ria of Ortigueira, however, this asymmetry is a consequence of the interaction between the different water bodies existing in the ria. In the outer part the ENACW was found mixed with coastal seawater where typical taxons of advanced stages of succession are dominant (Leptocylindrus or Guinardia). In the inner part, the continental supply of nitrate (Fig.4) favoured the fast growth of species indicatives of the initial stages of blooms (Chaetoceros). The importance of continental supply is confirmed by the higher dinoflagellates (Scrippsiella) abundance in the inner ria zone (Table 1).

The development of upwelling along the Northwesthern coast of Galicia arose on the coast of Cape Prior-Ortegal as a result of northeastern prevailing winds. The Ria of Ortigueira was not under the upwelling influence until the upwelling episode became strong and only then did affect that ria. Due to the changes of coastal orientation at Cape Ortegal the reason of the upwelling presence in the Ria of Ortigueira is the west-east evolution of the Prior-Ortegal upwelling. According to Gómez-Gesteira et al. (2006) Ekman transport is modulated by the presence of the coast varying in intensity and direction along the coast of Galicia: the spring-summer pattern is characterized by a high transport along the western coast while at the northern one, Ekman transport, occurs at a lower magnitude and is oblique to the shoreline. Because of the prevailing wind conditions in this transitional area between the two different coastal orientations, the coast with north-south orientation (Prior-Ortegal) is prone to upwelling of subsurface waters in spring and summer, whilst these conditions are not so favourable along the east-west coast (Ria of Ortigueira). Likewise, in the region of northern Morocco the coastal winds are weak and blow onshore because of the orientation of the coast, so upwelling is less pronounced than in adjacent areas (Mittelstaedt, 1991; Barton, 1998).

In the case under study, it must be also considered that the Cape Estaca-de-Bares is situated north of the eastern shoreline of the Ria of Ortigueira (Fig.1), and this could strengthen the upwelling intensity. Analytical models (Crepon et al. 1984) predict that the presence of a cape makes upwelling events stronger and more persistent, as pointed out for Cape Peñas (Botas et al., 1990; Llope et al., 2006) and Cape Ajo (Lavín et al., 1998) both of which are located along the central Cantabrian coast. Hence, Cape Estaca-de-Bares marks the coastal boundary of the summer upwelling of Galicia and its influence does not reach the Cantabrian Sea where occasional upwelling events were only found associated to capes.

Acknowledgements. The authors thank the R/V Lura crew for their kind assistance, Prof. Evans for English language improvements, and Drs Doval and Bernárdez for the analysis. This work was CICYT-FEDER financed (CTM2007-62546-C03/MAR). 


\section{References}

Alvarez, I., Gomez-Gesteira, M., deCastro, M., Novoa, E.M., 2008. Ekman transport along the Galician Coast (NW, Spain) calculated from QuikSCAT winds. Journal of Marine Systems 72, 101-115.

Alvarez, I., Ospina-Alvarez, N., Pazos, Y., deCastro, M., Bernardez, P., Campos, M.J., GomezGesteira, J.L., Alvarez-Ossorio, M.T. Varela, M., Gomez-Gesteira, M., Prego, R., 2009. A winter upwelling event in the Northern Galician Rias: frequency and oceanographic implications. Estuarine Coastal and Shelf Science 82, 573-582.

Alvarez, I., Gomez-Gesteira, M., deCastro, M., Gomez-Gesteira, J.L., Dias, J.M., 2010. Summer upwelling frequency along the western Cantabrian coast from 1967 to 2007. Journal of Marine Systems 79, 218-226.

Alvarez-Salgado, X.A., Miller, A.E.J., 1998. Simultaneous determination of dissolved organic carbon and total dissolved nitrogen in seawater by high temperature catalytic oxidation: conditions for precise shipboard measurements. Marine Chemistry 62, 325-731.

Alvarez-Salgado, X.A., Rosón, G., Pérez, F.F., Figueiras, F.G. and Pazos, Y., 1996. Nitrogen cycling in an estuarine upwelling system, the Ria de Arousa (NW Spain). I. Short-time-scale patterns of hydrodynamic and biogeochemical circulation. Marine Ecology Progress Series 135, 259-273.

Barton, E.D., 1998. Eastern Boundary of the North Atlantic: Northwest Africa and Iberia Coastal Segment (18, E). In: Robinson, A.R., Brink, K.H. (Eds), The Sea. John Wiley\&Sons, London, pp. 633-657.

Blanton, J.O., Atkinson, L.P., Castillejo, F., Montero, A.L., 1984. Coastal upwelling of the Rias Bajas, Galicia, northwest Spain, Hydrographic studies. Rapp. P.-v. Reun. CIEM 183, 79-90.

Botas, J., Fernandez, E., Bode, A.,Anadon, R., 1990. A persistent upwelling off the Central Cantabrian Coast (Bay of Biscay). Estuarine, Coastal and Shelf Science 30, 185-199.

Crepon, M., Richez, C. and Chartier, M., 1984. Effects of coastline geometry on upwellings. Journal of Physical Oceanography 14, 1365-1382.

Fernandez, E., Maranon, E., Cabal, J., Alvarez, F.,Anadon, R., 1995. Vertical particle flux in outer shelf waters of the southern Bay of Biscay in summer 1993. Oceanologica Acta 18, 379-384.

Fraga, F., 1981.Upwelling off the Galician Coast, Northwest Spain. In: Richards, F.A. (Ed.), Coastal Upwelling. AGU, Washington, pp. 176-182.

Gómez-Gesteira, M., deCastro, M.,Prego, R., 2003. Dependence of the water residence time in Ria of Pontevedra (NW Spain) on the seawater inflow and the river discharge. Estuarine, Coastal and Shelf Science 58, 567-573.

Gómez-Gesteira, M., Moreira, C., Alvarez, I., de Castro, M., 2006. Ekman transport along the Galician coast (northwest Spain) calculated from forecasted winds. Journal of Geophysical Research 111, C10005.

Hansen, H.P.,Koroleff, F., 1999. Determination of nutrients. In: Grasshoff, K.,Kremling, K., Ehrhardt, M. (Eds.), Methods of Seawater Analysis. Wiley-VCH, Weinheim, pp. 159-226.

Lavin, A., Valdes, L., Gil, J., Moral, M., 1998. Seasonal and inter-annual variability in properties of surface water off Santander, Bay of Biscay, 1991-1995. Oceanologica Acta 21, 179-190.

Llope, M., Anadon, R., Viesca, L., Quevedo, M., Gonzalez-Quiros, R.,Stenseth, N.C., 2006. Hydrography of the southern Bay of Biscay shelf-break region: integrating the multiscale physical variability over the period 1993-2003. Journal of Geophysical Research 111, C09021.

Margalef, R., 1978. What is an upwelling ecosystem? In: Boje, R. Tomczak, M. (Eds.), Upwelling ecosystems. Springer-Verlag, Berlin, pp. 12-14.

Mittelstaedt, E., 1991. The ocean boundary along the northwest African coast: Circulation and oceanographic properties at the sea surface. Progress in Oceanography 26, 307-355.

Neveux, J., Panouse, M., 1987. Spectrofluorometric determination of chlorophylls and pheophytins. Archiv für Hydrobiologie 109, 567-581. 
Ospina-Alvarez, N., Prego, R., Álvarez, I., deCastro, M., Álvarez-Ossorio, M.T., Pazos, Y., 2010. Oceanographical patterns during a summer upwelling-downwelling event in the Northern Galician Rias. Comparison with the whole ria system (NW of Iberian Peninsula). Continental Shelf Research 30, 1362-1372.

Penabad, E., Alvarez, I., Balseiro, C.F., deCastro, M., Gomez, B., Perez-Muñuzuri, V., 2008. Comparative analysis between operational weather prediction models and QuikSCAT wind data near the Galician coast. Journal of Marine Systems 72, 256-270.

Prego, R., 1994. Nitrogen interchanges generated by biogeochemical processes in a Galician ria. Marine Chemistry 45, 167-176.

Prego, R., Bao, R., 1997. Upwelling influence on the Galicia coast: silicate in shelf water and underlying surface sediments. Continental Shelf Research 17, 307-318.

Prego, R., Varela, M., 1998. Hydrography of the Artabro Gulf in summer: western coastal limit of Cantabrian seawater and wind-induced upwelling at Prior Cape. Oceanologica Acta 21, 145155.

Prego, R., Barciela, C., Varela, M., 1999. Nutrient dynamics in the Galician coastal area (northwestern Iberian Peninsula): do the Rias Bajas receive more nutrient salts than the RiasAltas? Continental Shelf Research 19, 317-334.

Sieburth, J. McN., V. Smetacek \& J. Lentz. 1978. Pelagic ecosystem structure: heterotrophic compartments of the plankton and their relationship to plankton size fractions. Limnology and Oceanography 23, 1256-1263.

Tenore, K.R., Boyer, L.F., Cal, R.M., Corral, J., García-Fernández, C., González, N., 1982. Coastal upwelling in the Rias Bajas, NW Spain: contrasting the benthic regimes of the Rias de Arosa and de Muros. Journal of Marine Research 40, 701-770.

Tomas, C.R., 1997. Identifying marine phytoplankton. Academic Press, New York, 858 pp.

Torres, R., Barton, E.D., 2007. Onset of the Iberian upwelling along the Galician coast. Continental Shelf Research 27, 1759-1778.

Varela, M., Prego, R., Belzunce, M.J., Martin-Salas, F., 2001. Inshore-offshore differences in seasonal variations of phytoplankton assemblages: the case of a Galician Ria Alta (Ria de A Coruña) and its adjacent shelf (NW Spain). Continental Shelf Research 21, 1815-1838.

Varela, M., Prego, R., Pazos, Y., Moroño, A., 2005. Influence of upwelling and river runoff interaction on phytoplankton assemblages in a Middle Galician Ria and Comparison with northern and southern rias (NW Iberian Peninsula). Estuarine Coastal and Shelf Science 64, 721-737.

Varela, M., Prego, R., Pazos, Y., 2008. Spatial and temporal variability of phytoplankton biomass, primary production and community structure in the Pontevedra Ria (NW Iberian Peninsula): oceanographic periods and possible response to environmental changes. Marine Biology 154, 483-499. 


\section{Figure legends}

Figure 1. Map of the Ria of Ortigueira showing the main geographical characteristics and the oceanographic sampling stations -black circles- of the cruise of June 2009. In the lower-right map full circles numbered 1 to 5 mark the hydrographical stations between Capes Prior and Ortegal. The control point for upwelling index calculation at coordinates $45^{\circ} \mathrm{N} 352^{\circ} \mathrm{E}$ is shown as an asterisk in the upper-left panel.

Figure 2. The averaged Ekman transport field in the open-sea (upper-left corner) and temporal evolution of the sea surface temperature (SST) images along the Northern and Northwestern coast of Galician during the studied upwelling event.

Figure 3. TS diagram corresponding to the sampling campaign at the stations located in the mouth of the Ria of Ortigueira, on the neighboring shelf (St. C, D and E; Fig.1) and between Capes Pior and Ortigueira (St. 1 to 5; Fig.1). The upper TS border of Eastern North Atlantic Central Water (ENACW) is highlighted as a broken line following Fraga (1981).

Figure 4. Sections of salinity, temperature, saturation percentage of dissolved oxygen and concentrations of nitrate, nitrite, ammonium, dissolved organic carbon (DOC) and chlorophyll along the Ortigueira section. 
Figure(s)

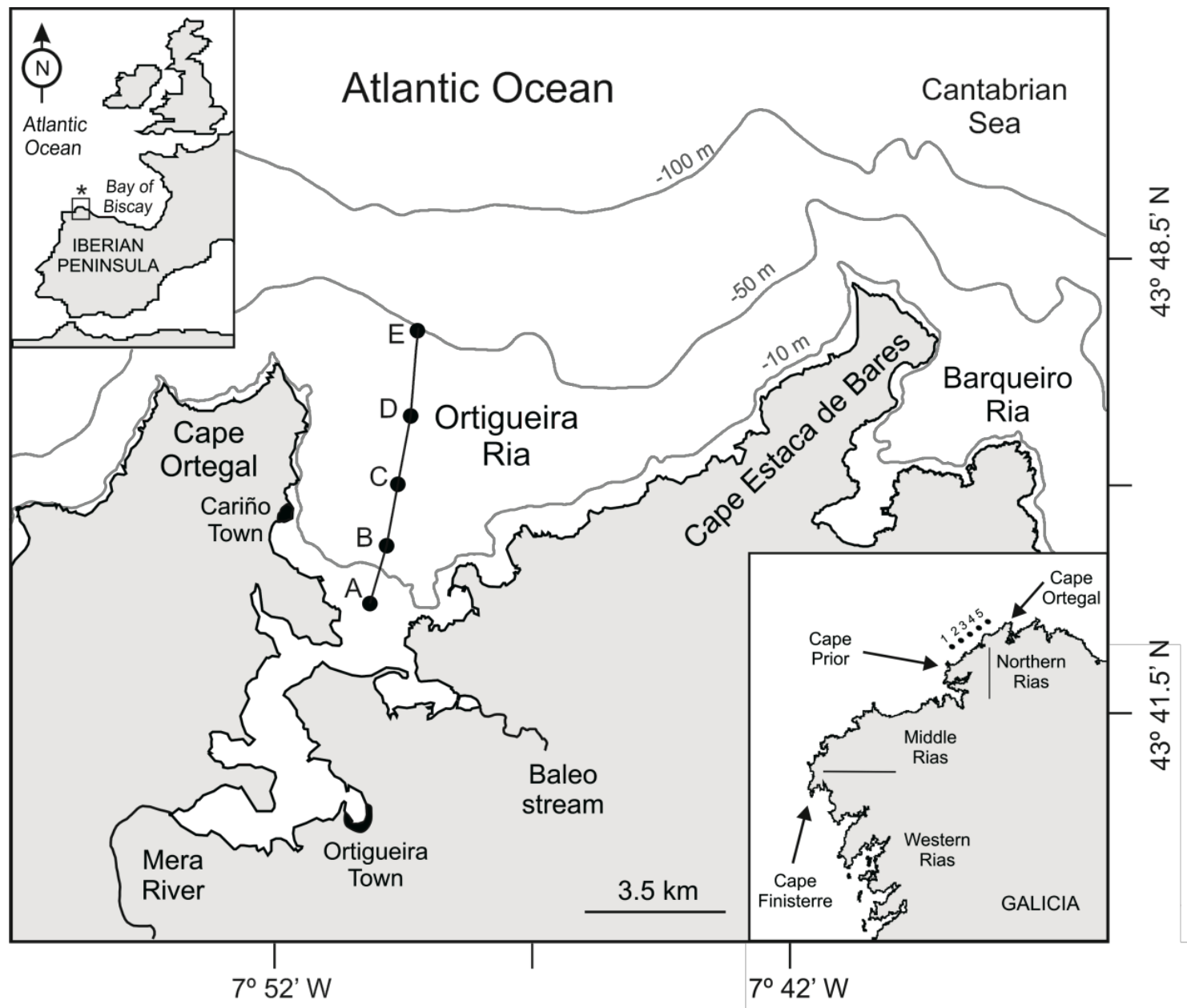

Figure 1 


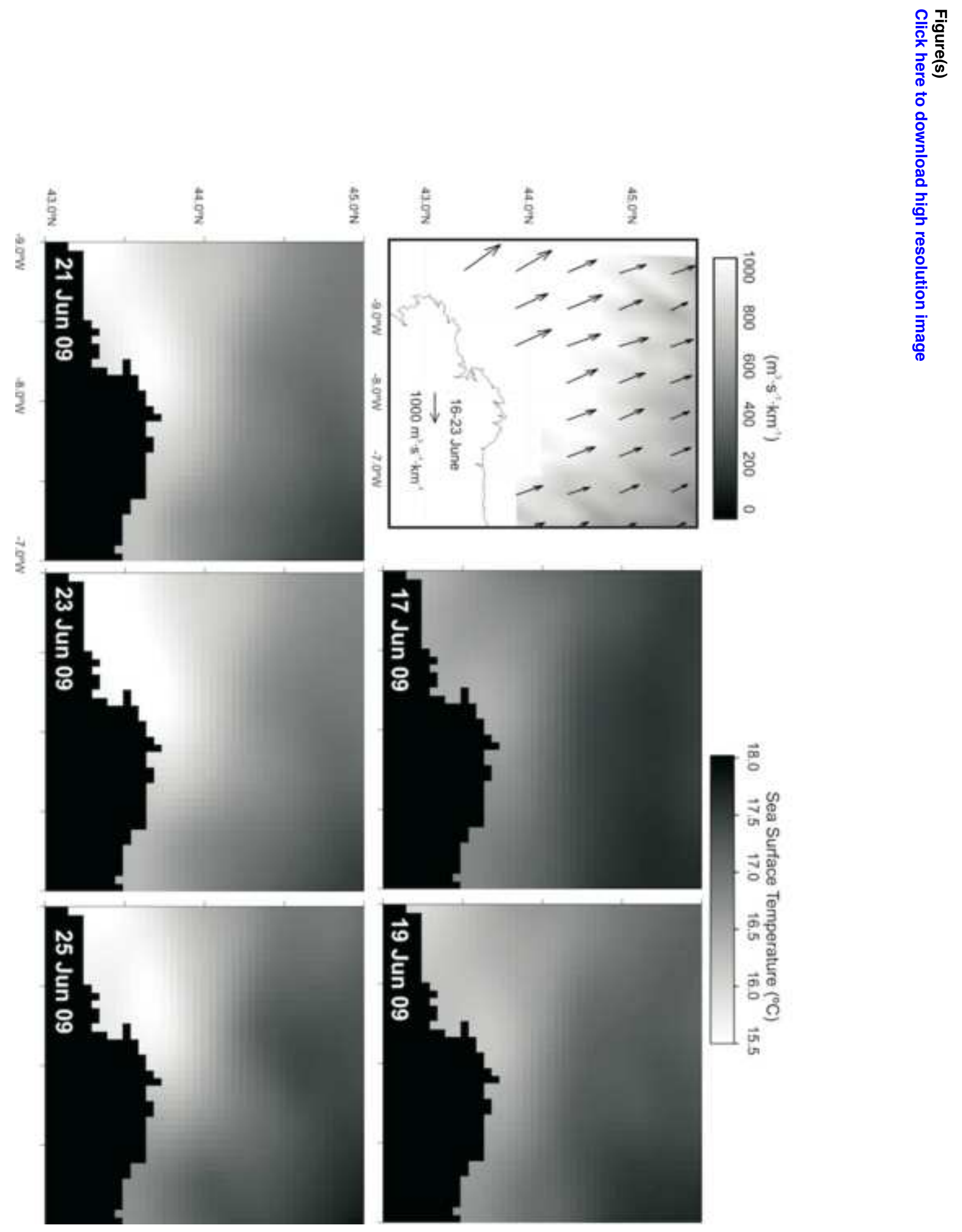


Figure(s)

Click here to download high resolution image
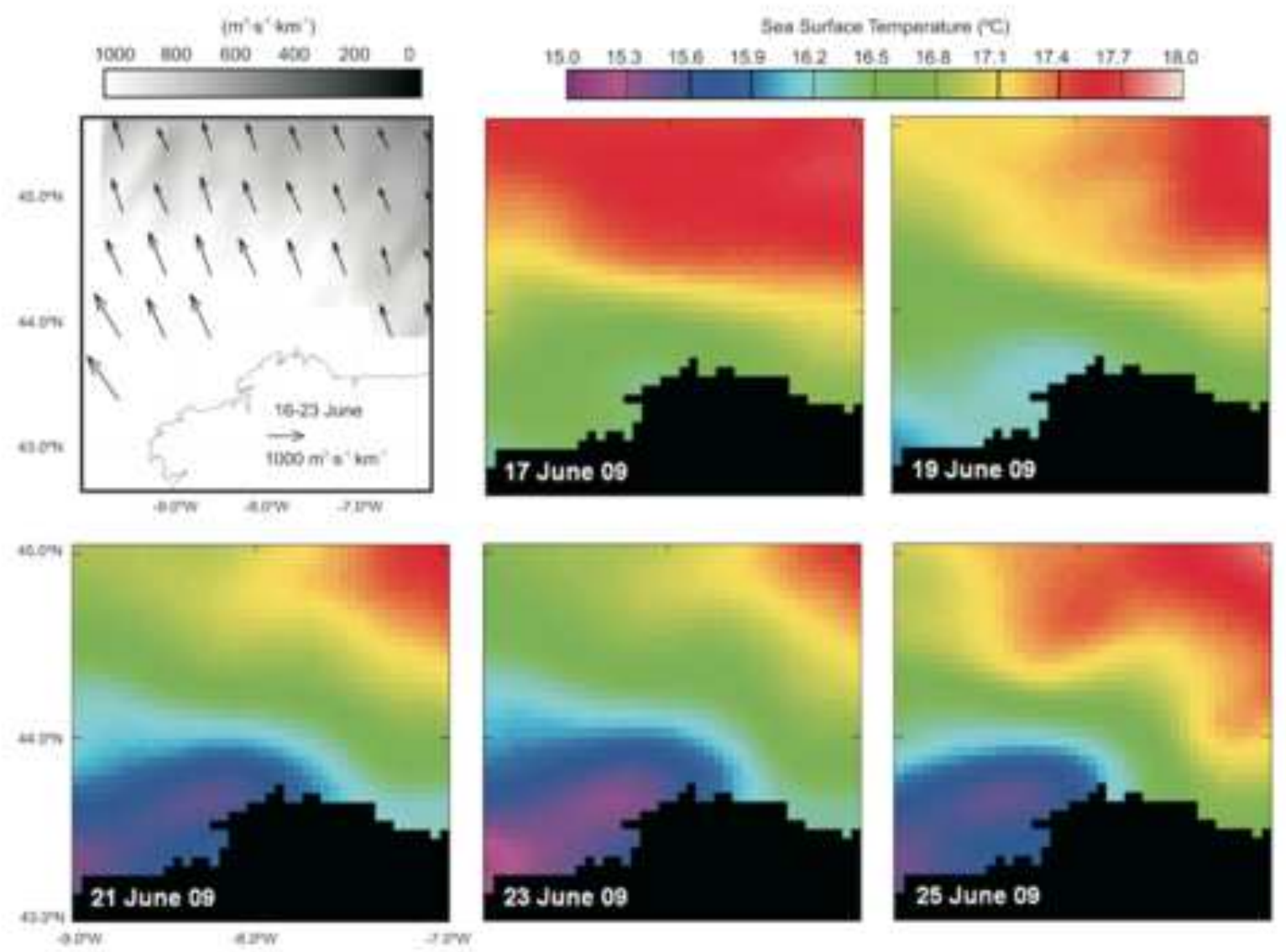
Figure(s)

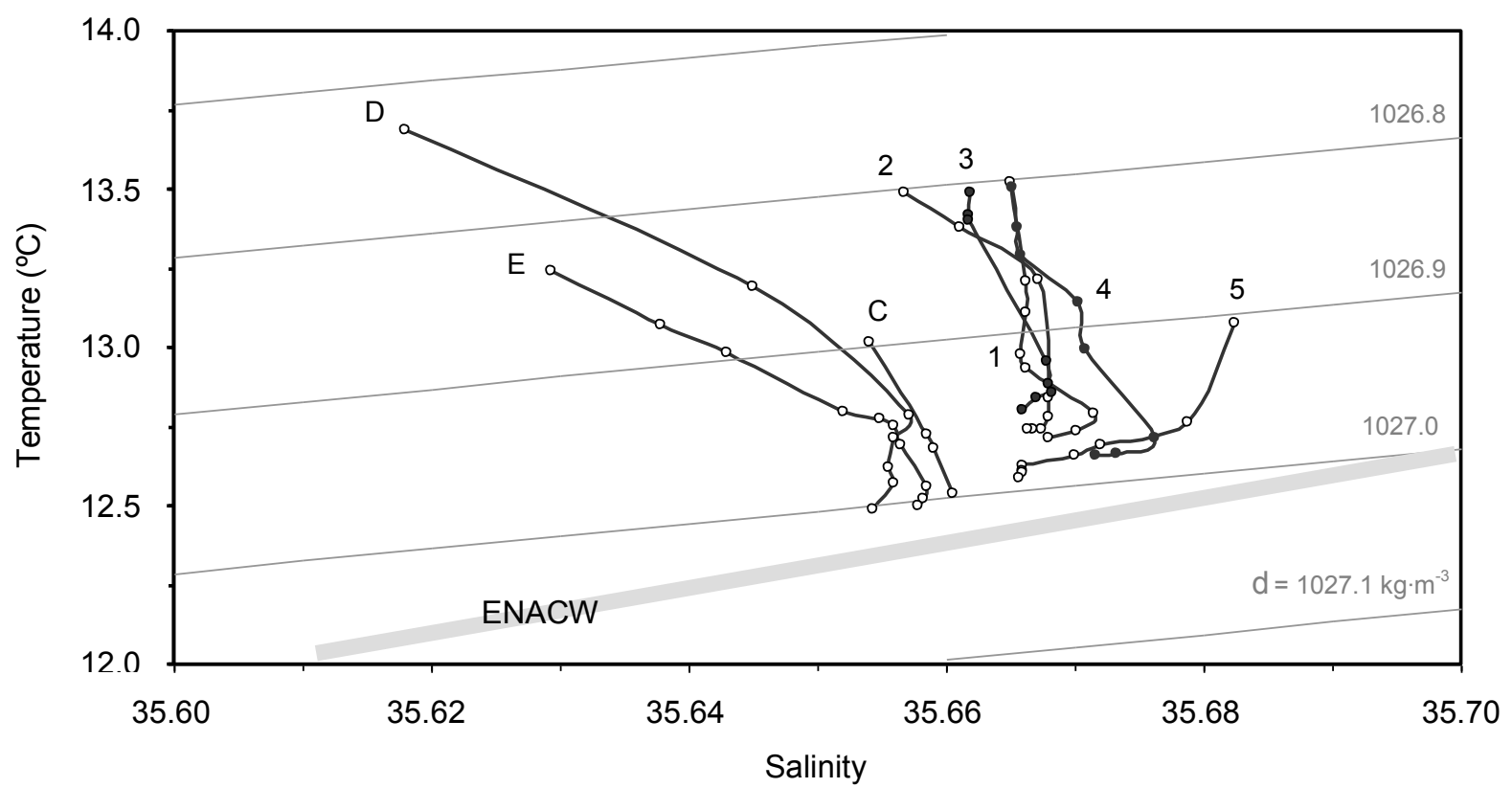

Figure 3 
Figure(s)
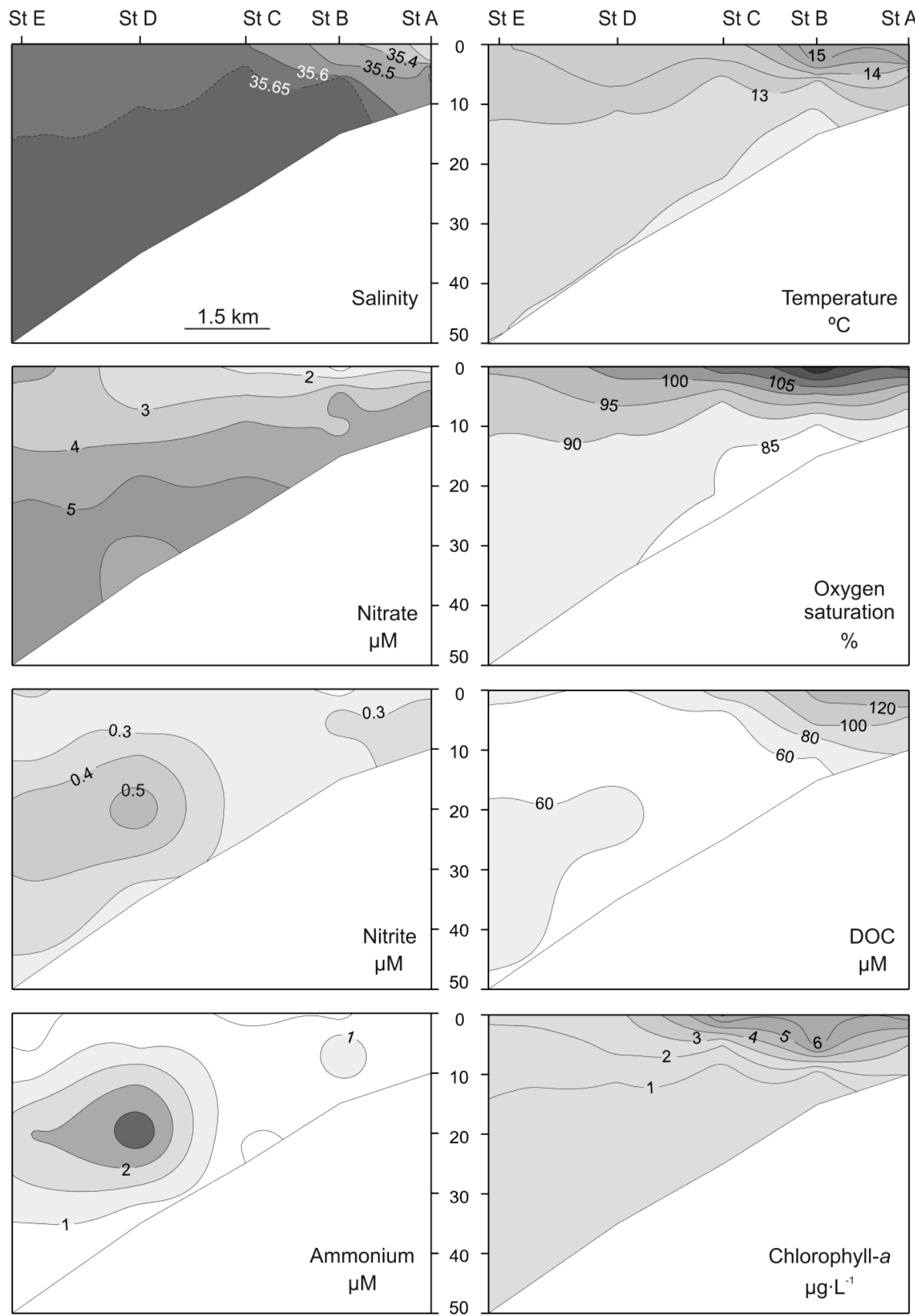

Depth (m)

Figure 4 
Table 1. Mean abundance of phytoplankton (cels $\mathrm{mL}^{-1}$ ) in the Ria of Ortigueira when the upwelling event reached the highest point (June 23, 2010). N: number of samples. X: mean, sd: standard deviation.

\begin{tabular}{|c|c|c|c|c|c|c|c|}
\hline \multirow[b]{2}{*}{ Group } & \multirow{2}{*}{$\begin{array}{l}\text { Station } \\
\text { Taxon }\end{array}$} & \multicolumn{2}{|l|}{ A } & \multicolumn{2}{|l|}{$\mathrm{C}$} & \multicolumn{2}{|l|}{$E$} \\
\hline & & $\mathrm{n}$ & $X \pm s d$ & $\mathrm{n}$ & $X \pm s d$ & $\mathrm{n}$ & $X \pm s d$ \\
\hline Cryptophyceae & Cryptomonas spp. & 2 & $24 \pm 143$ & 3 & $138 \pm 183$ & 3 & $33 \pm 17$ \\
\hline Chrysophyceae & Solenicola setigera & 2 & & 3 & & 3 & $17 \pm 14$ \\
\hline \multirow[t]{12}{*}{ Bacillariophyceae } & Chaetoceros affinis & 2 & $714 \pm 239$ & 3 & $416 \pm 278$ & 3 & $119 \pm 85$ \\
\hline & Chaetoceros socialis & 2 & $2320 \pm 161$ & 3 & $944 \pm 92$ & 3 & $199 \pm 43$ \\
\hline & Chaetoceros spp. & 2 & $138 \pm 72$ & 3 & $129 \pm 56$ & 3 & $77 \pm 51$ \\
\hline & Dactyliosolen fragilissimus & 2 & $22 \pm 22$ & 3 & & 3 & $1 \pm 1$ \\
\hline & Guinardia delicatula & 2 & $4 \pm 4$ & 3 & $3 \pm 3$ & 3 & $18 \pm 21$ \\
\hline & Leptocylindrus danicus & 2 & $64 \pm 11$ & 3 & $79 \pm 54$ & 3 & $184 \pm 94$ \\
\hline & Leptocylindrus minimus & 2 & & 3 & $26 \pm 24$ & 3 & $43 \pm 29$ \\
\hline & Nitzschia longissima & 2 & $25 \pm 14$ & 3 & $2 \pm 1$ & 3 & $4 \pm 1$ \\
\hline & Pseudo-nitzschia delicatissima & 2 & $6 \pm 6$ & 3 & $66 \pm 76$ & 3 & $26 \pm 13$ \\
\hline & Pseudo-nitzschia pungens & 2 & $43 \pm 43$ & 3 & $39 \pm 32$ & 3 & $23 \pm 7$ \\
\hline & Thalassiosira angulata & 2 & & 3 & & 3 & $20 \pm 12$ \\
\hline & Thalassiosira levanderi & 2 & $154 \pm 96$ & 3 & $66 \pm 35$ & 3 & $24 \pm 14$ \\
\hline \multirow[t]{3}{*}{ Dinophyceae } & Dinoflagellates $<20 \mu \mathrm{m}$ & 2 & $45 \pm 11$ & 3 & $27 \pm 21$ & 3 & $20 \pm 8$ \\
\hline & Dinoflagellatess $>20 \mu \mathrm{m}$ & 2 & $12 \pm 1$ & 3 & $5 \pm 3$ & 3 & $2 \pm 1$ \\
\hline & Scrippsiella trochoidea & 2 & $31 \pm 27$ & 3 & $7 \pm 8$ & 3 & $2 \pm 3$ \\
\hline \multirow[t]{2}{*}{ Flagellates } & Monads $<2 \mu \mathrm{m}$ & 2 & $828 \pm 6525$ & 3 & $720 \pm 559$ & 3 & $741 \pm 45$ \\
\hline & Monads 2-20 $\mu \mathrm{m}$ & 2 & $772 \pm 2704$ & 3 & $260 \pm 136$ & 3 & $280 \pm 232$ \\
\hline Prymnesiophyceae & Phaeocystis pouchetii & 2 & & 3 & & 3 & $25 \pm 23$ \\
\hline
\end{tabular}

